\title{
Lessons for Liberalism: Lord Brougham's Philosophy of Italian Politics
}

\author{
by Colin Pearce
}

\section{Introduction: The Republic of Venice and Lorenzo de Medici}

Henry Lord Brougham (1778-1867) is a figure who attained great fame and influence in the course of his public life but who may also be studied for his contributions to the tradition of liberal political philosophy.[1] In this discussion I hope to show the relationship between his treatment of Italian history and his political philosophy.

Venice forms a focus for Broughams historical attention because it is a regime that he thinks has much to teach the political philosopher. Brougham portrays Venice as a system of polity which presents no ordinary claims to our admiration. No government, Brougham says, ever had so long a duration as the Venetian with so little of sudden and violent change, and so few shocks from attempted revolution. But Brougham nevertheless forthrightly condemns the morality of Venetian politics even as he admits their efficiency. This extraordinary commonwealth triumphed because the very frame of government was so well calculated for the councils of deep, unscrupulous policy. Indeed, Nothing can be more profligate than the disregard of all principle, nothing more daring than the contempt of all engagements, nothing more heartless than the cold-blooded and calculating cruelty by which the republic was ever ready to compass her objects. [2]

Turning to the example of Florence, Brougham explains that Lorenzo de Medici used a mixture of fraud and violence to overthrow the popular government of 200 years. Lorenzo was guilty of disregard of human life and suffering upon more than one occasion. Yet because those who have written about him have been dazzled by Lorenzos achievements in the realm of what today we might call culture they have mistakenly exalted him as a benefactor of mankind and recounted his career without duly reprobating its darker shades.[3]

In these accounts of Venice and Lorenzo de Medici we see how Brougham wants political history to be written. There is political success on the one hand and the moral choices that facilitated it on the other. Brougham wants to be seen as appreciative of the one as well as discriminating with respect to the other. He is aware that there is a tendency amongst certain historians in his day to downplay the crimes of historical figures in terms of the prevailing ethical zeitgeist. Some might argue for example that the intrigues in which Lorenzo de Medici was confessedly engaged, such as his stirring up sedition and his enforcing of sanguinary executions and violent banishments were no more acts of treachery and cruelty, than the practice of the age and country rendered familiar. But (h)istorians do not reflect when they palliate the 
misdeeds of men whose merits in some particulars they may record, that their very virtues suffer by the association with crimes. [4] Elsewhere Brougham says that by far the greatest part of the encouragement held out to profligate conduct in those who have the destinies of nations in their hands may be ascribed to the historians of all ages. The power hungry oppressors who afflict humanity rely on the praise of historians for their enjoyment of power, or of fame, or of both. The fawning historians cause mankinds thoughtless admiration to be habitually lavished upon the conquerors that harass and enslave them.[5] But for precisely this reason it is within the power of these historians to give some practical discouragementto the worst enemies of our species. They might do so by using their art not to glorify tyrants and usurpers but to deny to the would-be tyrants the praise they seek. They can help to reduce the level of tyranny and oppression by simply describing the ease, worth, and happiness of blessed peace as well as celebrating the progress of science and of art, the extension of security and freedom, the improvement of national institutions, (and) the diffusion of general prosperity[6] Broughams target here is almost certainly his old rival within the Whig camp Thomas Babington Macaulay. Macaulay had famously declared that Niccol Machiavellis peculiar immorality belonged rather to the age than to the man and was a partial taint, and by no means implied general depravity. For Macaulay the real explanation of Machiavellis nefarious political principles is to be found in the state of moral feeling among the Italians of those times. [7] In other words, Machiavelli was very much a child of his time and as such cannot be condemned unqualifiedly as a teacher of evil.[8] But Brougham is at odds with his Whig colleague here. He thinks that those who have accepted Macaulays argument that the immorality of the Italian Renaissance should be attributed to the state of moral feeling among the Italians of those times have most likely been blinded to the treachery and bloodthirstiness of the likes of Lorenzo by the encouragement Lorenzo gave to learned men.[9] But it is the historians duty always to be morally severe on political figures whatever the desirability of the flourishing of the arts and sciences at all times and places. He who permits literary excellence, or the encouragement of artists, to abate his dislike of perfidy and cruelty, forgets that letters and the arts do contract a stain by being found to ally themselves with the baser propensities of our nature instead of keeping us above such contamination. [10] The Whig Interpretation of History Macaulay was the most famous of the nineteenth century Whigs and he had drawn Broughams fire by affiliating his Whiggish history with the view that morality is not absolute but rather is historically relative.[11] So it is paradoxical in the extreme that the most famous attack on the Whig historiographical tradition we have that of Herbert Butterfield was made precisely for its absolutism and its insensitivity to the mitigating factors of the relative historical context. In attacking The Whig Interpretation of History Butterfield was laying bare what he thought were people like Broughams essential limitations and in so doing he sounds for all the world like Broughams Whig colleague Macaulay. But Butterfield was writing a century later than Brougham and so he chose as his absolutist target none other than Lord Acton.[12] Acton plays the role of a stand-in for Broughams judgmental view of history in Butterfields discussion. Butterfield rightly describes Acton as being afraid of "too much explaining, lest we end by too much excusing" tout comprendre, c'est tout d'excuser. But why would Acton and Brougham go out of 
their way to deny the somewhat obvious point that historical conditions explain much about the way people think morally and therefore act politically?[13] The BroughamActon response to this question is clear - if we accept the case that it is the age rather than the man which is the real moral agent in the executions, persecutions, banishments etc. about which we acquire knowledge then a sanction is given to further such actions if they should have a fair chance of success. [14] Brougham and Acton want us to be shocked by the crimes of Lorenzo and the ideas of Machiavelli. We cannot afford to be dismissive of the moral evil we see peeking at us from behind their deeds and thoughts. The Whig Macaulay and the anti-Whig Butterfield both arrive at a position indistinguishable from a historical relativism that would excuse the human sacrifice of the Aztecs as well as the cruelties perpetrated upon them by the Spanish Conquistadores for example.[15]

In response to such Whiggish moral certitude Butterfield claims that such a judgmental or moralistic approach to the past has the practical effect of curtailing the effort of historical understanding.[16] It means that an undefined region is left to the subjective decision of the historian, in which he shall choose not to explain, but shall merely declare that there is sin. Such a view involves a shortcut to the absolute. Indeed, the only absolutism that the Whig is disposed to defend is that of the decision of the historian. But for Butterfield this is a mistake because the historian has no interest in an absolute system, equally binding on all places at all times. Though morality may be seen as absolute by some it is not absolute to him.[17] One simply cannot pronounce a simple and absolute moral judgment on the likes of Lorenzo or Cesare Borgia or any other historical actor. All the historian can do is give evidence that Napoleon lied, that Alexander VI poisoned people and that Mary Tudor persecuted. Indeed, it is not an historian but the theologian St. Thomas Aquinas who really gives expression to the Brougham-Acton view when he states that we should "Suffer no man and no cause to escape the undying penalty which history has the power to inflict on wrong."[18]

From Butterfields point of view then Lords Acton and Brougham are not even writing history. To the extent that they engage in moral judgments they have left the realm of historical explanation which is neither more nor less than the process of seeing things in their context. The moral responsibility which Brougham-Acton seeks to apportion in their historical presentations in fact lies altogether outside the particular world where the historian does historical thinking.[19]

\section{The Objects of Government and the Limits of Politics}

Against this background of Butterfields attack on Whig history we can appreciate more clearly what it is Brougham is attempting to do in his treatment of Italian history. He is not interested in simply examining the changes of things which change. Rather his conception of history is such that it involves assessing individual figures and regimes according to a standard in accordance with which he is prepared to praise and blame, admire and condemn. His goal is to show how political science or philosophy is capable of deriving knowledge from historical studies of what 
individual statesmen and governments ought to do not just of what they have in fact done.

The basis of all Broughams discriminations in his treatment of the history of Italy or of any other country for that matter is his theory of "the objects of all government" or of the ends of "all political society." These objects, to speak generally, include domestic harmony, social stability, economic growth, national security and the avoidance of war. The implicit meaning of this theory of the objects of government is that the best politics is less politics. By this I mean that the absolutism (to use Butterfields language) which Brougham is indeed prepared to defend is that government should absolutely confine itself to secur(ing) life and property at a moderate expense of personal liberty[20] These objects of government are rooted in the nature of man itself and are not in fact relative to their time and place however much their attainment might be affected by conditions of time and place. If indeed we can come to a more precise understanding of the true objects of government then we have a standard of measurement by which to assess how well this or that form of government has performed in this or that historical environment. And if we can assess how well this or that form of government has performed in relation to the rationally determined ends of political life we can arrive at something, which deserves to be called political science. We seek such a science because we seek an answer to the question What is politics? Another way of phrasing this question is to ask where does politics stop and the other or non political elements of human life begin? Only when we have managed to draw such a line will we avoid the dangerous confusion of the proper sphere of politics with other things that a truly outside its scope.

Broughams political philosophy then is designed to show us how politics should fit into human Dasein as a whole (to use Heideggers famous term). His aim is to point to the impropriety of subsuming under strictly or narrowly political categories endeavours that should remain free to be what they should be regardless of any external considerations, e.g. the cultivation of art, science, literature and religion. Only if we understand the nature of the true objects of government will we appreciate where Machiavellianism or immoral politics goes wrong or is self-refuting. In Broughams hands Lorenzo de Medici and the Venetian Republic come to symbolize the view that politics isnt everything, its all there is (to paraphrase a famous football coach of Italian descent). They reveal what it means to have all of human life cut down to fit a procrustean bed the dimensions of which are determined by politics and politics alone. The reason for Broughams lack of sympathy with this hyper political philosophy of life are not hard to find in the details of his own career. Although it is true that he was indeed a supremely political type who at one time had a chance to become Englands Prime Minister, a full treatment of his career would have to cover his endeavours in literature, science, theology, philosophy, belles-lettres, languages and so on.[21] In other words, Broughams own interests extended far beyond politics narrowly defined in terms of power.[22] Thus he paints an unsympathetic portrait of historical characters and governments that subordinate all other considerations to their lust for power. Power and rule may be an unavoidable and elemental feature of political life but they should not be represented as constituting all of it. Students of politics should never forget that there is something broader and nobler than even the 
legitimate objects of government and that is the development of our humanity made possible precisely by confining government to its legitimate objects. Thus we always find Brougham alluding to this or that ruler or governments role in relation to the arts and sciences or to university or church reform and related questions. In the case of Italian history its sheer variety and eventfulness makes it the perfect data bank in which the political philosopher might undertake research into the price to be paid when the prevailing authorities adopt the view that politics is all there is which is to say include in the list of their political objects things other than securing of life and property at a moderate expense to liberty. And by the same token Italian history can provide the materials needed to outline the benefits to be reaped when politics is confined to these ends which is to say avoids the politicizing of those essentially non political pursuits which make possible the fullest development of human nature.The Best Regime

It follows from what we have seen above that for Brougham political philosophy is ultimately about the desire for the best form of government as a means to the best condition of humanity. Brougham sincerely believes that a much purer and more noble government than has characterized the historical record would be constituted by a legislature of wise, virtuous, and enlightened men, with an executive council of capacity, integrity, and firmness, removed from popular control, animated with a desire for furthering the public good, and consulting in the pursuit of it, no will or authority but their own chastened judgment.[23] However Brougham is certain that a scheme which embodied all these ingredients is to all intents and purposes an ideal or utopia. And the reason for this is that human beings are by nature too much prone to pursue their "own individual interest." This will remain the case, Brougham says, "until we are blessed with a descent of angels to undertake the management of our concerns."[24] In the absence of these quasi-divine assistants, Brougham is forced to the conclusion that "there is but one security for the community" and this consists in "a watchful superintendence and efficient control over its representatives and rulers." (U)nhappily, experience has proved that any legislature, and any executive body, removed from all control, soon forgets the end of its creation; and instead of consulting the good of the community at large, confines all its exertions to furthering its own individual interest. The fundamental fact Brougham claims, is that "any system that excludes the popular voice must needs lead to oppression and to abuses which admit of no compensation, and, instead of wearing out in time, only gather strength and acquire increased malignity with every year that revolves." Thus there is only one option left as a reigning principle - and that is a government which owes its origin to public choice, and acts under the people's superintendence. [25]

But while insisting that government must be answerable to the people at some level Brougham nevertheless denied that "the people are the source of all power or that all power whatever (comes) from the people. Speaking anthropologically or in terms of the concept of an initial social contract as outlined by Hobbes, Locke and Rousseau, Brougham follows his fellow Scot David Hume. The "utmost we can say, is that there may, in many instances, perhaps more or less in all," have been "acquiescence (to government) on the part of the people.[26] The corollary Brougham is aiming at here is that a government cannot qualify as "just and legitimate" simply in virtue of its 
stemming from the people. Rather popular power is every bit as illegitimate as monarchical power if it diverges from the purposes of government demonstrated by the discipline of social science or political philosophy properly so called.

Broughams complete ambivalence on this problem is in evidence when we notice that elsewhere he is on the side of Lockes Right to Revolution. Even though the right to resist tyrannical authority is "an extremity and should be cautiously embraced it is necessary that both governors and the governed should regard the recourse to that extremity as always (being) possible." History teaches that the people never can be safe without a constant determination to resist unto the death as often as their rights are violated."[27] According to Brougham then government should be beyond simple dependence on the vagaries of popular will as well as apprehensive lest it trigger the peoples right to resist unjust rule. Broughams retreat from the strict popular sovereignty doctrine then is in the name of something like natural justice. Government is legitimate only when and if it is just, not simply when it can be certified as popular.

This central ambiguity in Broughams political philosophy is further observable in his analysis of the relationship between public opinion and good government. He is sure that the pressure of public opinion on governmental authority is in general to the good. The politics of the petty states of Italy reveal that the absence of public opinions influence on the governing classes is a bad thing. The princes of Parma and Modena have no dread of public opinion, because their subjects are too well watched by them and their agents to express their hostile sentiments freely. The public voice is not heard in meetings, or clubs, or newspapers, because the sovereign power imposes silence; and that power is by the silence rendered more uncontrolled.[28] Parma and Modena need to see the pressure of popular sentiment acting as a brake on the government.

But while making such an observation Brougham is also equally sure that popular sentiment should not be accepted as an absolute and unqualified political principle. How to explain this seeming contradiction? An answer lies in the fact that for Brougham "there is a wide difference between Democracy and all other forms of government" with respect to the operation of public opinion. There can be little doubt that the pressure of "popular hatred and contempt" in places like Parma and Modena can be a restraining influence on a tyrant or oligarchy. The tyrant, though he exercises the "most despotic sway," is nevertheless "subject to fear." This fear keeps men like him, and to a somewhat lesser extent a class of nobles should they hold power, in "dread of enraging the people." But this check of popular sentiment takes on a radically different complexion under democratic conditions. In places like Parma and Modena the opposition is between the absolute rulers and popular opinion, but under democratic conditions the struggle is between justice itself and popular opinion in all its force. Whereas popular sentiment might serve a good end under non-democratic conditions, in a democracy mere flattery becomes the food generally offered up, and he who goes before others in the extravagance of his doctrines, or the violence of his language, outbids his competitors in popular favour.[29] 
So while Brougham fully execrates the "mutual suspicion and terror" upon which absolute despotism depends he adds that "it is more easy to escape the agents of a royal tyrant than those of the vulgar scourge." Looking forward to Bolshevism and National Socialism perhaps, he observes that once "the predominance of one party in a Democracy has been fully established, there is no safety for those who differ with it by ever so slight a shade."[30] In other words while the check of public opinion can operate in despotic governments in their dealings with the people it cannot by definition influence the people themselves directly." As the effective power holders in a democracy the people themselves are secure from all personal risk, and beyond the reach of censure." Party rule with full popular support has a totalitarian aspect not seen under non-democratic conditions. In the case of "the sufferer who is oppressed by a tyrant or an oligarchy" there is the possibility that the "sympathy of the people" may offer "some help and relief." But there is no sympathy for "the people's victim." In the end, his "sufferings are exacerbated by the howl of popular execration and scorn," something which "falls heaviest upon the most delicate and sensitive natures." Democracy makes possible the "tyranny of the multitude" which is all the more "intolerable" as it "pervades the whole community searchingly and oppresses the humblest as well as the highest."[31]

So given Broughams evident pessimism about the potential for governments both popular and non-popular to serve justice can he cite for us any actual historical example of a better form of government which points the way to the best possible polity if not the rule of a descent of angels? There is one such example in Broughams writings and it is indeed from the annals of Italian history - the reign of the Albizzi in Florence. [32]

\section{The Albizzi Regime}

According to Brougham, the Albizzi party governed Florence for above half a century with great success, extraordinary ability, and as much virtue as could well be expected in that age and among that people. The Albizzi regime, he explains, combined two political alternatives in a most significant way. They were of the "Guelf or liberal and democratic party" while at the same time being "supporters of popular nobility or New Aristocracy." Thus they had the democratic and aristocratic principles combined in one governmental authority. What was the general result of this combination? Domestically considered it made the government moderate while at the same time allowed it to be generally speaking vigorous. In addition to moderation and vigour the Albizzi were also distinguished for being "the patrons of genius in every department" of "literature, science, and all the fine arts." In foreign affairs the Albizzi regime pursued an enlarged and disinterested policy which raised the name and influence of the republic while consulting the interests of all Italy and afford(ing) everywhere protection to national independence.[33]

To say the least, Broughams seems like an idealized portrait of the Albizzi regime. But why such an idealization? I think the explanation lies in Broughams wish to praise the mixing of the democratic and more aristocratic elements or the wisdom of such a 
scheme. It is certain that the democratic power in no other Italian commonwealth was attended with so wise and vigorous an administration, and in none produced so few of the evils in foreign affairs inseparable from that scheme of polity. [34]Jeremy Bentham may have impugned the notion of a balance between democracy and aristocracy as absurd and the reasoners who followed his line of argument may have treated it as a miraculous fancy" but Brougham is undeterred.[35] But Brougham is sure that mixed government possesses "three great advantages...over every other. These are "its protecting the public interest from the risk of rash, ill-concerted councils, its securing the freedom and rights of all classes of the community, and its maintaining the stability of the political system."[36] The "constantly enjoyed benefits of equal rights, good government, and security against widespread revolution show that this Mixed System will conduce more to the people's interests, than a removal of all the obstruction which the checks and balances can create." Brougham concludes that mixed government has "so many and such precious virtues" that in comparison its attendant vices, (e.g. the multiplication of parties), "lie within a narrow compass indeed."[37]

It is for coming close to this picture of mixed government that Brougham paints such a rosy picture of Albizzi Florence. Brougham is implicitly saying to his English readers: Look at Albizzi Florence and all the wonderful effects of mixing democratic power and popular nobility or New Aristocracy. Surely the Whigs have done the right thing in reforming the British Constitution in this direction. History in general, and Italian history in particular shows us the good effects we should expect as a result of the Whig reforms in Britain. In Broughams hands we see Italys potential to give Britain a gift of far greater value than that of trade, diplomacy, alliance and culture it can given her statesmanlike prudence and political wisdom.

Of course there can be no doubt that Brougham is being a-historical or anachronistic in his laudatory treatment of Albizzi Florence. In painting such a political portrait he has to abstract from the manifest differences in religion, law, science and culture between the $15^{\text {th }}$ century Italy and $19^{\text {th }}$ century Britain. Although Athens is often referred to as the cradle of western democracy it is customary to promptly point out that Athenian direct democracy is very different in nature from our more modern, constitutional, representative form of government which goes under the same name. In consequence the two should not simply be identified as earlier and newer versions of fundamentally the same thing. The confusion of Athenian democracy with democracy as it is practiced in Europe and North America today would be avoided grossly imprecise. Similarly the life of a small city-state in Renaissance Italy cannot reasonably be described as liberal in a sense appropriate to Victorian Britain. None of the institutional safeguards or legal procedures painfully built up in the English Constitution as described so famously by Walter Bagehot in his study of 1867 would have been seen even in the Florence contemporary to Brougham let alone in the Florence of over four hundred years previous.[38] So we are entitled to ask why Brougham appears to write in such a way that two regimes separated by four centuries as well as by language, religion and culture somehow reflect of one another? 
Broughams intention in painting his portrait of the Albizzi regime is evidently not historical and comparative accuracy in any scientific sense. He assumes that his readers are fully aware that Italy around 1400 constituted a different world from Britain in the around 1840 . He rather intended to isolate the praiseworthy features of the Albizzi regime in the context in which they emerged and then to make them come to sight as progressive tendencies. Allowances for time and place, for differences of religion, public enlightenment, economic activity, social class etc. are assumed in his idealized account. The best regime around 1400 in Italy was Albizzi Florence and the best regime around the mid 1800 s in Europe is that of Whig Britain and for the same basic reasons. A regime which manages to combine a strong element of democratic power with a balancing element of wise and vigorous administration is much to be desired whatever its historical context. The precise proportion of the combining elements may vary but the blending of popular sympathy with enlightened decisionmaking has been shown to be one of the first principles for the advancement of civilization.

All this makes Brougham a classic exponent of a modernized version of Aristotles polity which is the regime dominated neither by the rich nor the poor but by the more enlightened, responsible classes in between. But we know that Aristotle also carefully considered the merits of monarchy and concluded that in principle it was the best form of government while also recognizing that in practice it is liable to degenerate into tyranny. Does Brougham follow Aristotle on this question as well? After all enlightened despotism was the original liberal paradigm in the thought of Hobbes who founded the tradition to which Brougham ultimately belongs. Brougham does in fact opt for Aristotles reservations about monarchy rather than Hobbes arguments for its advantages. In a word, pure monarchy is a very good idea that should never be tried. Brougham makes his thinking clear in his assessment of Leopold I of Tuscany. [39]

Leopold I of Tuscany Broughams describes Leopold I as a ruler who ended vexatious monopolies, favoured freedom of trade, and reformed the municipal law in a wise spirit. In particular Brougham likes Leopolds dealing with Tuscanys religious affairs. He abolished the Inquisition, placed the monastic orders under the jurisdiction of local bishops, reformed the discipline of the clergy, forbade the ecclesiastical courts to encroach on secular jurisdiction and subjected the priests to trial for crimes by the secular courts. He also promoted agriculture, reformed the universities of Sienna and Pisa, abolished torture and capital punishment, and encouraged the local administration of towns and parishes. For a quarter of a century Leopold governed upon the principles of a policy at once virtuous and wise and as a result of his administration Tuscany has largely enjoyed as much happiness as almost any nation in Europe, and far more than any other Italian people. For all these achievements, Brougham says, Leopold I of Tuscany deserves a very exalted place among the sovereigns who have deserved well of mankind. [40] But for all this Brougham does not translate the case of Leopold I into a case for monarchical government as a principle. Leopolds statesmanship, Brougham says, would almost justify the predilections entertained by some philosophers for unlimited power vested in a single 
ruler (emphasis added). [41] But why the almost here? Brougham answers that the predilection for monarchy could only be fully justified if we could reasonably expect many princes to remain, like Leopold, uncorrupted by the enjoyment of supreme authority.[42] But on this point the case for unfettered monarchy breaks down. (T)he appearance of such sovereigns is inevitably a rare occurrence. Moreover their invariably good conduct cannot even be safely reckoned upon. Even a long course of good government such as Tuscany has at different times enjoyed, offers no argument in mitigation of the sentence which all reason and all experience pronounces upon pure monarchy. And As if to warn us against any such lenient feelings, close by Tuscany is placed Modena, with a constitution not more absolute and a sovereign of the same house, and yet we have seen how its people are oppressed and its concerns mismanaged. One might say that despite or because of the example of Leopold I the Italian experience leads Brougham away from monarchy rather than towards it. Indeed, The lesson which a contemplation of all absolute monarchies teaches is that such a frame of government never can afford any security to the people against the greatest sufferings from oppression and from mismanagement of their affairs. Moreover this particular lesson is more forcibly inculcated by those of Italy than any other.[43] But why is this lesson so well learnable from the history of Italy compared to that of Broughams own country of Great Britain? It is because in Italy there were a greater number of absolute monarchies and therefore a consequent variety of administration which can be studied. Analyzing the Italian monarchies teaches us an important truth never to be lost sight of which is that the natural tendency of unrestrained power is to corrupt the best natures. [44] Or in the proverbial words used later by the Lord Acton who was so vigorously criticized by Herbert Butterfield Power corrupts, and absolute power corrupts absolutely. Lord Actons famous principle is presented by Brougham as deriving not from some a priori moral premise but from the data supplied by Italian history. Brougham wishes for us to accept the truths of political science because they can be arrived at empirically or via a process of historical induction. These truths may well be accessible to non-empirical speculation but to see them emerge via the inductive method, to have them adduced from the real experiences of Italian history can only add to the weight they will carry. But there is one question Brougham needs to address given that he is writing at the moment when the British Empire is rising to the height of its dominance as the modern Rome and assuming increasing responsibility for a large segment of the human race. What is the optimal size of the best polity? Should it be small or large, of limited size or of great extent? For an answer to this question Brougham also finds the history of Italy of invaluable assistance.

\section{Petty States: The Problem of Size}

We have seen Brougham agree with Aristotle on the wisdom of mixing the democratic and aristocratic elements in government and on the desirability but practical inadvisability of the rule of the one best individual. Brougham also agrees with Aristotle that an important subject of consideration for political philosophy is the desirable size and extent of the city. As part of the process of coming to a conclusion on this subject Brougham studied communities like Lucca, Parma and Modena in 
order to assess the impact of narrow extent upon their governments, their administration, and the condition of their inhabitants. [45] Whatever his other areas of agreement with Aristotle his conclusion on this question is at odds with the founder of political science who had said that the truly good society, the society which is most conducive to virtue is one of limited size and modest population.[46]

Brougham explains that the principal evil arising from a politys limited extent is nothing less than the more arbitrary nature of (its) government. In smaller communities the sovereign is brought so near every individual, above all so near every one of influence that a party adverse to the power of the court can expect little support from the petty community. There is only an insignificant risk from insurrection and as a result in the course of time every institution opposing a barrier to the prerogative falls into ruin, or remains only to be a restraint in form and in name.[47]

Petty states then are distinguished by a lack of room for society to go its own way. In a narrow community, Brougham says, the prince and his court are constantly interfering, meddling, busying themselves about all persons and all things, to a degree which the inhabitants of larger states cannot easily conceive.[48] Not a purchase can be made, a lawsuit carried on, a marriage contracted, or any other family arrangement settled, but the princes or their officers must take a part in the matter.men's words as well as their actions being under perpetual watch, a disrespectful expression is punished; oftentimes the false report of one is acted upon as true; and always the fear of such visitations haunts those exposed to such risks.[49] Intrinsically then, more so than accidentally as might be the case with large polities, petty states tend to be totalitarian in nature. Broughams description reminds us of todays debate over citizens being monitored by CCTVs, checks on emails and internet usage and so on. The problem which some aspects of rapid technological advancement poses for us is posed by smallness of size and population in Brougham.

Another element Brougham sees as detracting from the politics of small states resonates with Thomas L. Friedmans recent discussions of globalization and the earth being flat.[50] This is the problem of the intercourse of the inhabitants (of petty states) with their near neighbours becoming nearly as difficult as that with foreign nations. The men of Parma for example have constant occasion to communicate with those of Modena; but there is as much trouble with passports and custom-houses as an Englishman finds on entering France. Communities like Parma and Modena are all frontier and this means that in some cases when Parmans wish to resort to the capital of their own country, at only twenty miles distance, they must be provided with passports, which have to be examined, and their baggage searched, five or six times, both going and returning.[51] Brougham would no doubt have been happier for the Parmans and Modeneses if they lived as citizens of todays European Union the goal of which is to make the free movement of all persons between member countries without let or hindrance a reality.[52]

\section{Conclusion}


Broughams manifest concern with domestic freedom from government surveillance and interference and with the free movement of people and goods across borders reveals the ideal implicit in his philosophy of Italian politics. He shares with modern, western liberalism the assumption that the world is tending, and should tend towards a community of free and independent states governing populations of free and independent citizens. The faction-ridden and strife-torn past of the Italy points its students ahead from present in which they are making their discoveries towards a future where the ease, worth, and happiness of blessed peace is within the reach of all peoples.[53] The history of Italy may have been one of endless faction and war but the future of mankind has the potential at least to be one of Perpetual Peace.[54]

[1] Brougham took over the teachings of the liberal tradition stretching back to Locke and Montesquieu although his immediate mentors within this tradition were his fellow Scottish thinkers Hume, Smith, Gibbon, Robertson, Stewart and Mackintosh. This tradition of thought takes on a particular hue and complexion in Brougham according to his own insights and situation as a political actor attempting to foster the growth of liberal democracy within the British world. The more well known writers who have expressed opinions on Brougham in one way or another include Walter Bagehot, Leslie Stephen, John Henry Cardinal Newman, John Stuart Mill, Landor Praed, Lord John Campbell and Crane Brinton.

[2] Political Philosophy 3 vols. (London:Chapman and Hall, 1842; Charles Knight, 1844) 2:279.

[3] Political Philosophy, 1:630. Brougham is referring here to the historian of the British Constitution Henry Hallam (1777 - 1859). Hallam is famous for his work Constitutional History of England published in the 1820 s which became a standard reference work in the field. See Thomas Babington Macaulay, "Hallam," Edinburgh Review (September,1828) http://www.history1700s.com/etext/html/texts/1cahe10.txt Brougham makes an exception in the case of M. Sismondi. Jean Charles Lonard de Sismondi $(1773$ - 1842) was a Geneva born political economist. In 1807 the first volumes of his Histoire des Republiques Italiennes du moyen age establishing him as a major figure in the Republique des Lettres. Sismondi worked on this project for another eleven years eventually extending it to sixteen volumes. .

[4] Political Philosophy, 1:630

[5] Political Philosophy, 1:634-45

[6] Henry Brougham, "Robertson," in The Works of Lord Brougham 11 vols. (Edinburgh: Adam and Charles Black,1872)2:269-270.

[7] Machiavelli, Macaulay: Prose and Poetry (London: Rupert Hart-Davis,1967), 263

[8] We shall not shock anyone, we shall merely expose ourselves to good-natured or at any rate harmless ridicule, if we profess ourselves inclined to the old fashioned and simple opinion according to which Machiavelli was teacher of evil. Leo Strauss, Thoughts on Machiavelli (Seattle and London: University of Washington Press, 1969),9. 
[9] Political Philosophy, 1:629.

[10] Political Philosophy, 1:630-31

[11] Harry Elmer Barnes says that since the Second World War the two chief culprits for the promotion of historical relativism have been Carl L. Becker and Charles A. Beard. A History of Historical Writing (New York: Dover,1962), 394

[12]John Emerich Edward Dalberg-Acton, 1st Baron Acton, (1834 - 1902) was a Catholic thinker and historian who became the Regius Professorship of Modern History at Cambridge in 1895. Lord Acton at the end of the nineteenth century, believed it his duty to make overt moral judgments; Mr. A.J.P. Taylor, writing in the middle of the twentieth century, does not. Arthur Marwick, The Nature of History (London: Macmillan, 1970), p.21.

[13] The essentials of this wicked relativism so far as Becker, Beard, and those sympathetic to their point of view are concerned, are the following veritable historical truisms (1) reconstructing the past exactly as it was (is impossible) (2) historical truth depends upon the mental climate of the period as on the validity of the facts themselves. Barnes, A History etc., p. 395

[14] (T)he realization of universal evil is a sanction for more evil, hence the great danger of truth. Truth does not propagate itself, but is always prostituted. Wyndham Lewis, "Machiavelli's Candour" The Lion and the Fox (London: Methuen,1966), p.212.

[15] See Colin D. Pearce, Prescotts Conquests: Anthropophagy, Auto-da-fe and Eternal Return Interpretation: A Journal of Political Philosophy 24(Spring, 1997),339-361

[16] While allowing that it is a sound position to view Machiavelli as a teacher of evil Leo Strauss nevertheless refers with obvious approval to Goethes description of Sir Walter Scott as a historian who precisely because he makes an effort to judge deeds in a pious and conscientious spirit and who strictly guards himself against the whole Machiavellian view has deprived himself of exactly that view without which one would hardly wish to concern oneself with the history of the world. Thoughts on Machiavelli, 329n1

[17] The Whig Interpretation of History. http://www.eliohs.unifi.it/testi/goo/butterfield/ For Butterfield, the achievement and the function and the defence of history is that it inquires and explains and in so doing increases human understanding, extending it to all the ages, and binding the world into one. Such a statement sounds remarkably like an absolute moral standpoint with which Lord Brougham would find no reason to disagree.

[18] Butterfield, The Whig Interpretation etc., http://www.eliohs.unifi.it/testi/9oo/butterfield/

[19] Butterfield The Whig Interpretation etc., http://www.eliohs.unifi.it/testi/90o/butterfield/

[20] Political Philosophy, 1:658-59.

[21] See Colin D. Pearce, Lord Broughams Neo-Paganism. The Journal of the History of Ideas (October,1994):651-670.

[22] Robert A. Nisbet says that the the opposition of power to authority is one of the unit ideas of European sociology in its great formative period 1830-1900. The Sociological Tradition (New York: Basic Books, 1966), 4. 
[24] Works, 5:306. Brougham is echoing the sentiments of Publius in Federalist 51: But what is government itself, but the greatest of all reflections on human nature? If men were angels, no government would be necessary. If angels were to govern men, neither external nor internal controls on government would be necessary. http://www.constitution.org/fed/federa51.htm

[25] Works, 5:307. For Brougham the principle of representation, an invention of modern times, is the greatest of all improvements which have ever been made in the science of government and legislation. Political Philosophy, 3:37. Compare James Mackintosh Dissertation on the Progress of Ethical Philosophy (Edinburgh: Adam and Charles Black, 1835), p.308; James Mill An Essay on Government (New York: The Liberal Arts Press,1955),p.67; Sir Henry Sumner Maine, Popular Government (London: John Murray,1918),93-95. Alexander Hamilton "Federalist No.9." The Federalist Papers, Clinton Rossiter ed.(New York: New American Library,1961),72-73

\section{[26] Political Philosophy, 1:646}

[27] Political Philosophy, 1:646. Compare Hume, Moral and Political Philosophy (New York: Hafner,1972), 360. In Broughams estimation it would be difficult to speak in terms of too great commendation of Humes Political Discourses Works 2:176.See also Mill, Essay On Bentham (New York: New American Library,1962), 114-115; John Austin, The Province of Jurisprudence Determined ed. W. Jethro Brown (London: John Murray,1906),,p.200; and Francis Lieber, On Civil Liberty and Self-Government (Philadelphia:J.B.Lippincott,1859),398-409.

\section{[28] Political Philosophy, 1:646}

\section{[29] Political Philosophy 3:119}

[30] Political Philosophy, 3:119. Nietzsche exclaimed: (L)et our watchword be: More respect for the man of knowledge! And down with all parties! Human, All Too Human, Vol. 2, Aphorism \#318.

[31] Political Philosophy, 3:120; Works, 11:3. From the eighteenth centurys generally optimistic vision of popular sovereignty we pass to nineteenth century premonitions of the tyranny that may lie in popular democracy when its institutional and traditional limits are broken through. Robert A. Nisbet, The Sociological Tradition (New York: Basic Books, 1966), 9.

[32] The Albizzi family based in Arezzo was the rival of the Medici and Alberti families between 1382 and 1424 when the Medici attained full power.

[33] Political Philosophy, 2:352

[34] Political Philosophy, 2:352

[35] Political Philosophy, 2:5

[36] Political Philosophy, 3:158

[37] Political Philosophy, 3:161. Brougham is politically open to the possibility that mixed government may at some point in social development become superfluous. As long as there is evidence of the incapacity of the people to govern themselves mixed government is a wise and beneficial arrangement. But remove this incapacity and the reasoning in favour of mixed government weakens correspondingly. "The whole question, therefore, is whether or not the people are likely to improve 
themselves so much as to be quite capable of self-government.(ibid.)

[38] Walter Bagehot, The English Constitution http://www.gutenberg.org/etext/4351. John Stuart Mill says in his speech to Parliament of April 21,1868: There are on the Continent great and enlightened countries, in which normal procedure is not so favourable to innocence, does not afford the same security against erroneous conviction, as it does among usBut we all know that the defects of our procedure are the very opposite. Our rules of evidence are even too favourable to the prisoner, and juries and Judges carry out the maxim, It is better that ten guilty should escape than that one innocent person should suffer, not only to the letter but beyond the letter. http://ethics.sandiego.edu/Books/Mill/Punishment/index.html

[39] Leopold I of Lorraine (1747-1792) also known as Pietro Leopoldino ruled Tuscany from 1765 to 1790 before becoming Holy Roman Emperor for two years before his death. His image is that of a reform minded progressive who sought to remove the last remnants of serfdom, was enthusiastic for trade, commerce and industry and sought to bring efficiency to the bureaucracy.

\section{[40] Political Philosophy, 1:635-636.}

[41] Broughams discussion of Leopold I points very clearly in the direction of the theory of monarchy as advanced by Henry St. John, Viscount Bolingbroke (1678-1751). Bolingbroke was not a Divine Right Tory but an enlightenment monarchist. He sought to promote a more modern form of society under the aegis of his Patriot King who would provide a shortcut to the liberal and progressive society. Instead of abetting the divisions of his people, the Patriot King will endeavour to unite them, and to be himself the centre of their union. Instead of putting himself at the head of one party in order to govern his people, he will put himself at the head of his people in order to govern, or more properly subdue all parties. The Patriot King will render public virtue and real capacity the sole means of acquiring any degree of power or profit in the State. Henry St. John, Viscount Bolingbroke, The Idea of a Patriot King (New York: Bobbs-Merrill,1965; orig. pub 1749),5-6, 39.

\section{[42] Political Philosophy, 1:635}

\section{[43] Political Philosophy, 1:678}

\section{[44] Political Philosophy 1:678-79}

[45] Political Philosophy, 1:646. Brougham stresses time and again that since the discovery of the principle of representation all previous assumptions in the discipline of political philosophy have to be revised, including the one subscribed to by Montesquieu that republican government over a large territory is impossible. In the light of the discovery of the representative principle there are no arguments against combining popular freedom with extensive size. It is possible now "to frame societies both upon a very different scale and upon very different foundations from those of the commonwealths of ancient times. Political Philosophy, 3:52.

[46] Brougham does not feel that there has been any great exaggeration in the invective engaged in by both statesmen and political reasoners in general concerning the evils inflicted upon the people by the turbulent and factious commonwealths of both ancient and modern times. In Broughams view we should reflect upon the mischiefs, at least equally intolerable, which arbitrary power, exercised over a small state, never fails of entailing upon its inhabitants. His conclusion is that a petty principality, is as much more unbearable than an extensive monarchy, as a petty republic is worse than a great commonwealth. Political Philosophy, 1:648.

[47] Political Philosophy, 1:646 


\section{Nordicum-Mediterraneum}

[48] Political Philosophy, 1:646

[49] Political Philosophy, 1:646

[50] The World is Flat (New York: Farrar, Strauss and Giroux, 2005)

[51] Political Philosophy, 1:648

[52] Political Philosophy, 1:646-47

[53] "Robertson," Works 2:269-270

[54] See Immanuel Kant, Perpetual Peace, and Other Essays on Politics, History, and Morals (Indianapolis: Hackett,1982)

Colin D. Pearce holds a Ph.D. in political science from the University of Toronto and has published in a variety of journals including Humanitas, Perspectives on Politics, Canadian Journal of Political Science, Journal of the History of Ideas, Interpretation, Clio, Appraisal, The Kipling Journal, The Simms Review and The South Carolina Review. He has been the William Gilmore Simms Professor at the University of South Carolina as well as the President of the South Carolina Political Science Association. He has taught at a variety of universities and colleges, most recently at the University of Guelph-Humber and the University of South Carolina Beaufort. 